University of Nebraska - Lincoln

DigitalCommons@University of Nebraska - Lincoln

8-27-2008

\title{
Hugo Who? G. F. Arnold's Alternative Early Approach to Psychology and Law
}

\author{
Brian H. Bornstein \\ University of Nebraska-Lincoln, bbornstein2@unl.edu \\ Steven D. Penrod \\ John Jay College of Criminal Justice
}

Follow this and additional works at: https://digitalcommons.unl.edu/psychfacpub

Part of the Psychiatry and Psychology Commons

Bornstein, Brian H. and Penrod, Steven D., "Hugo Who? G. F. Arnold's Alternative Early Approach to Psychology and Law" (2008). Faculty Publications, Department of Psychology. 336.

https://digitalcommons.unl.edu/psychfacpub/336

This Article is brought to you for free and open access by the Psychology, Department of at DigitalCommons@University of Nebraska - Lincoln. It has been accepted for inclusion in Faculty Publications, Department of Psychology by an authorized administrator of DigitalCommons@University of Nebraska - Lincoln. 
Published in Applied Cognitive Psychology 22:6 (2008), pp. 759-768; doi 10.1002/acp.1480; in a special issue on "Basic and Applied Issues in Eyewitness Research: A Münsterberg Centennial Retrospective." Copyright (C) 2008 John Wiley \& Sons, Ltd. Used by permission.

Portions of this paper were presented at the "Off the Witness Stand" conference hosted by the John Jay College of Criminal Justice, March 1, 2007, and in an invited address at the University of Nevada-Reno, October 8, 2007.

Published online August 27, 2008.

\title{
Hugo Who? G. F. Arnold's Alternative Early Approach to Psychology and Law
}

\author{
Brian H. Bornstein ${ }^{*}$ and Steven D. Penrod ${ }^{* *}$ \\ * Corresponding author; Department of Psychology, 238 Burnett Hall, University \\ of Nebraska-Lincoln, Lincoln, NE 68588-0308, USA; email bbornstein2@unl.edu \\ ** John Jay College of Criminal Justice, New York, NY 10019, USA
}

\begin{abstract}
Hugo Münsterberg is widely regarded as the founder of the discipline of psychology and law, and the publication of his book On the Witness Stand (1908) is considered the signal event in its founding. However, numerous other researchers were conducting and publishing research on psycholegal topics in the late 1800s and early 1900s, and at least one other book on psychology and law G. F. Arnold's Psychology Applied to Legal Evidence and Other Constructions of Law (1906)-appeared prior to the publication of Münsterberg's work. The present paper contrasts these two seminal publications, focusing on their relevance to the "basic-versus-applied" debate in contemporary eyewitness memory research and exploring reasons why Münsterberg has been so influential while Arnold has been largely ignored.
\end{abstract}

The field of psychology and law, as a formal (and especially as an experimental) discipline, is frequently deemed to have been "founded" with Hugo Münsterberg's publication of On the Witness Stand in 1908 (see Figure 1). The desire to identify a discrete seminal event, rather than the cumulative effect of a variety of forces, is understandable, though misplaced (Kuhn, 1970); in psychology and law, it obscures the key influences of research on criminology (e.g., Lombroso, 1876) and suggestibility (Binet, 1900), as well as other contemporaneous research on eyewitness testimony (Whipple, 1909, 1910, 1911, 1912, 1913, 1914). Curiously, it also ignores contemporaneous efforts to integrate the two disciplines.

For example, 2 years before the publication of Münsterberg's monograph, George Frederick Arnold published Psychology Applied to Legal Evidence and Other Constructions of Law in (1906) (see Figure 1). The present paper seeks not to detract from Münsterberg's status, but to resurrect Arnold as a forgotten forebear of psychology and law, by introducing his text to contemporary readers. We begin with an abbreviated overview of work conducted in psychology and law in the late 1800s and early 1900s (for a fuller treatment of this topic, see Doyle, 2005; Sporer, 1992, 2008), focusing especially on Münsterberg and Arnold. Next we contrast the scope of their respective texts, particularly with regard to the degree that they emphasize theory versus application in eyewitness memory research. We 


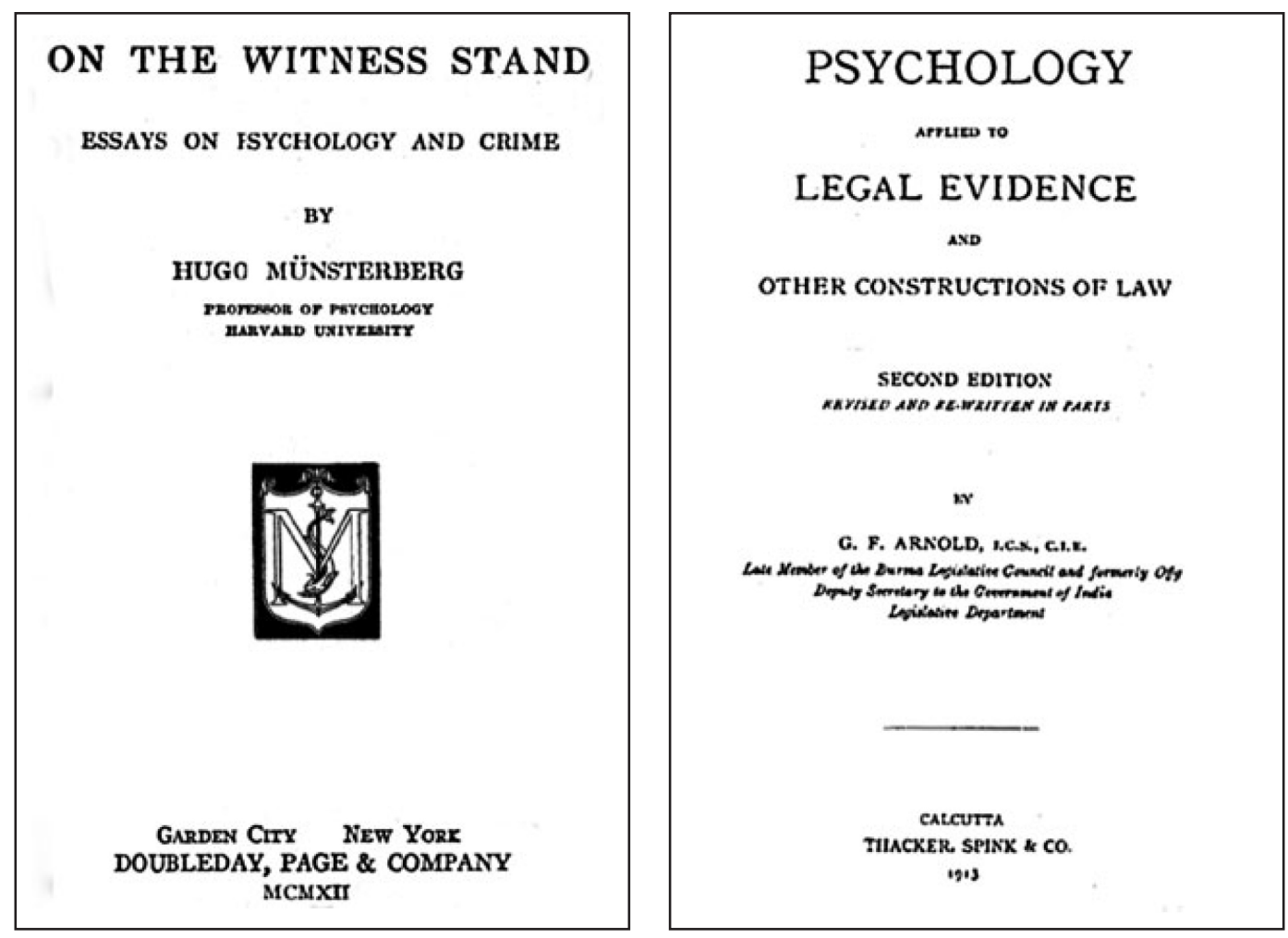

Figure 1. Münsterberg's and Arnold's title pages, both from second editions

then explore several possible reasons why Arnold has been relatively neglected. We conclude with a discussion of what G. F. Arnold in particular, and a historical approach in general, can teach the current generation of eyewitness memory researchers (and maybe future generations as well).

\section{Early Work On Psychology And Law}

Applications of psychology to the legal system began almost as soon as psychology became an experimental science in the late 1800s (for review, see Doyle, 2005; Greene, Heilbrun, Fortune, \& Nietzel, 2006; Sporer, 1992, 2006, 2008; Whipple, 1909, 1910, 1911, 1912, 1913, 1914; Wigmore, 1909). An incomplete list of prominent figures in the history of psychology who addressed legal questions includes Alfred Binet, James McKeen Cattell, Edouard Claparède, Sigmund Freud and Otto Lipmann (for bibliographies, see references cited above). The preeminent legal psychologist prior to Münsterberg's arrival on the scene was probably William Stern, who published several papers on eyewitness memory (see e.g., Sporer, 1992; Stern, 1907-1908) and founded a journal devoted to the topic in 1903 (Beiträge zur Psychologie der Aussage or Contributions to the Psychology of Testimony). Related work was being done around this same time in the field of criminology (e.g., Gross, 1897/1905; Lombroso, 1876). Thus, the field of psychology and law was a vibrant one at the turn of the 20th century, with work being done on two continents and in at least four different languages (English, French, German and Italian). The first books 
that concentrated on psychology and law were (to our knowledge) those published by Münsterberg (1908) and Arnold (1906).

Then, as now, there were two main reasons for the enterprise of applying psychology to law and, in some instances, vice versa. First, the law is rich with testable psychological assumptions; thus, legal contexts provide a convenient setting in which to test psychological theories dealing with such phenomena as memory, decision making, the relationship between attitudes and behaviors, etc. Second, legal contexts afford an opportunity for psychological scientists to have an impact in the real world. These dual rationales set the stage for the tension between basic and applied approaches that has characterized psychology in general, and the law-psychology field in particular, since the beginning. For example, it was central to the debate between introspectionism and behaviorism in the early 1900s (Thorne \& Henley, 2005) and has been a bone of contention among members of the American Psychological Association since its founding in 1892 (Benjamin, 1997). These divergent approaches were epitomized, to a large extent, by the work of Münsterberg and Arnold.

\section{Brief biographies of the protagonists}

Without delving into the treacherous waters of psychobiography, one can make the case (as we do later in this paper) that part of the reason for Münsterberg's and Arnold's disparate influence lies in their backgrounds and professional accomplishments. Thus, we briefly summarize what is known about the two men.

Münsterberg's story is fairly well known (Hale, 1980). He came from a wealthy German Jewish family, although he later converted to Lutheranism, mainly to obtain better educational and professional opportunities. He earned his Ph.D. in physiological psychology under Wilhelm Wundt at the University of Leipzig in 1885, and subsequently his M.D. at the University of Heidelberg. Despite being trained in Wundt's rigid introspectionist approach, he began criticizing Wundt's work almost immediately after taking a faculty position at the University of Freiburg. Because Wundt was such a dominant figure in German psychology at the time, Münsterberg was amenable to accepting an invitation to succeed William James in running the psychology laboratory at Harvard University in 1892, which he did with considerable success (Benjamin, 2000, 2006). He wrote as much for the popular press as for an academic audience; in fact, On the Witness Stand was largely a compilation of papers that had previously been published in popular magazines such as McClure's.

Münsterberg remained on the Harvard faculty until his death in 1916, although he increasingly grew tired of experimental studies and concentrated on applications of psychology to industrial/organizational and educational settings as well as to the law. He had strong nationalistic sympathies and was not shy about expressing them, which led to his being suspected of spying for Germany during World War I. Because of this, as well as his outspokenness on other public matters (such as highly publicized trials), he became unpopular and was something of a figure of ridicule toward the end of his life (Hale, 1980).

In contrast to Münsterberg, who is routinely touted in history of psychology texts as being the father of applied psychology generally ${ }^{1}$ (and legal and industrial-organizational psychology in particular; see e.g., Benjamin, 2000, 2006; Spillmann \& Spillmann, 1993; Thorne \& Henley, 2005), current psychology and law and forensic psychology textbooks

${ }^{1}$ Benjamin (2006) notes that despite this legacy, Münsterberg was not always a proponent of applied psychology. 
(e.g., Bartol \& Bartol, 2004; Costanzo, 2004; Greene et al., 2006; Wrightsman, 2001) make no mention of Arnold. On his book's title page (see Figure 1), he is identified as "Offg. Deputy Secretary to the Government of India, Legislative Department, and late Acting Divisional Judge, Prome, Burma." The British Library catalogue indicates that he was also the likely author of the 20-page "Monograph on Cotton Fabrics and the Cotton Industry in Burma," published in Burma in 1897 (Arnold, 1897). So apparently he was a British civil servant and judge, who spent most of his career at various outposts of the British Empire. Interestingly, Arnold might have been better known in the legal community than in the psychological community. Wigmore (1909), the noted dean of American evidence law, includes Arnold's book in the Appendix of his satirical critique of On the Witness Stand. It is somewhat ironic that Wigmore should evince a broader familiarity with relevant psycholegal research than Münsterberg, whose book is in large part an indictment of the legal community for its ignorance of that research.

\section{The Scope Of Münsterberg's and Arnold's Texts}

Münsterberg's book was immediately noted by both lawyers and psychologists. Probably the most prominent, lasting and damaging notice it received was Wigmore's (1909) scathing critique, which depicted a mock trial in which Münsterberg was charged with libelously damaging the law profession's reputation (Doyle, 2005; Sporer, 2006). Wigmore argued, and documented with a thorough review of the experimental literature, that psychology was not sufficiently mature as a science to make the legal contributions that Münsterberg claimed it could.

Arnold's book did well enough to have a second edition in 1913, after which it apparently dropped from sight. In the foreword to the second edition, he stated that both Münsterberg's work and Stern's Beiträge had come to his attention since he published the first edition. Pleading an inability to read German, he acknowledged utilizing Münsterberg's work but not Stern's. As most experimental work at the time was published in German, this limitation would necessarily give Arnold's book a non-experimental slant.

Arnold's familiarity with the psychology literature of the day is impressive in its breadth as well as depth of understanding. He cites experimental findings by researchers such as Wundt and Binet, and he spends considerable time discussing psychologically inclined philosophers like Berkeley and Bain, as well as those who bridged the gap between philosophy and psychology in the late 1800s (e.g., Stout, Höffding, Ward, Sully and Ribot). James' influence is especially noticeable: Arnold is very accepting of "supernatural" or "paranormal" phenomena such as hyperesthesia (an abnormal increase in sensitivity to sensory stimuli), hypnotism, thought-transference and somnambulism.

A comparison of the tables of contents of the two volumes shows a fair degree of overlap (see Table 1). Both Arnold and Münsterberg treat perception, memory, suggestibility, hypnotism, emotions/feelings, intention/volition and the relationship between belief and reality (e.g., in the context of confessions and insanity). Other topics are unique to one or the other volume. For example, Arnold's chapter on the "normal man" addresses what we would nowadays refer to as the law's "reasonable man" (or person, or, in some cases, woman) standard. He concludes that it is in many ways an empty construct, both legally and psychologically. Münsterberg, for his part, introduces criminological topics such as the prevention of crime.

Despite the substantial overlap in topics, the works differ in two principal ways: interdisciplinary emphasis and tone, or style. Although both are explicitly interdisciplinary, 
Table 1. Arnold and Münsterberg: Tables of Contents

\begin{tabular}{lll}
\hline Chapter & Arnold & Münsterberg \\
\hline 1 & General introduction & Introduction \\
2 & Intention & Illusions \\
3 & Intention (cont'd) & The memory of the witness \\
4 & Memory & The detection of crime \\
5 & Attention, the senses, introspection, inference & The traces of emotion \\
6 & The normal man & Untrue confessions \\
7 & Causation & Suggestions in court \\
8 & Belief, doubt, tests of truth, reality & Hypnotism and crime \\
9 & Feeling, imagination, prejudice, habit & The prevention of crime \\
10 & Insanity & \\
11 & Insanity (cont'd), intoxication, sleep & \\
12 & Hallucinations, illusions, hypnotism & \\
13 & Identity, similarity, comparison of handwriting & \\
14 & Ameer Ali and Woodroffe's edition of the & \\
15 & Indian Evidence Act psychologically examined & \\
16 & Responsibility, punishment, justice & \\
\hline
\end{tabular}

Münsterberg pays scant attention to legal theory or process while criticizing the courts for ignoring psychology. Arnold, in contrast, addresses legal issues and theories (e.g., causation, intent) at length and cites leading English legal scholars of the day such as Stephen (1883) on criminal law and Best (1849) on evidence. Thus, one could characterize Münsterberg's book as psychology against law, and Arnold's book as psychology and law.

The main way that the texts differ is in their tone. Arnold presents more basic research and theory, and he writes in the dry, somewhat pedantic style that characterizes most scholarly writing of the era. When he disagrees with other writers, he does so gently and with circumlocutions. In short, his book reads like the serious academic tome that it is. Münsterberg's style, on the other hand, is conversational, confrontational and blunt. His emphasis is much more applied, and he makes frequent use of anecdotes. As such, his book is easier to read, at least for most modern readers.

Consider, for example, their treatments of memory. Arnold addresses cognitive processes broadly (e.g., principles of association, general principles of memory), whereas Münsterberg focuses more on specific examples and applications (e.g., a personal anecdote about his memory and testimony regarding his own house burglary; a staged crime experiment). Virtually all of Münsterberg's chapter deals with memory as applied to the legal system, namely, eyewitness memory. Arnold relates several topics to eyewitnesses (e.g., collaborative recall), but he does so in the context of presenting the psychology of memory more broadly. He describes a number of phenomena of great theoretical relevance, then and now. Without necessarily using current terms, he clearly refers to such phenomena as flashbulb memory ("The effect of fear, so far from hindering recollection, is to aid it by giving exceptional vividness, distinctness and persistence to the images called up at the time," p. 112); mood congruency ("Still we can produce new griefs and raptures by summoning up a lively thought of their exciting cause, and though the cause is now only an idea it produces the same organic irradiations . . . which were produced by its original, so that the emotion is again a reality," pp. 126-127); the importance of retrieval cues; remembering versus knowing; reconstructive memory, which he calls "infer- 
ence"; using temporal order as a retrieval cue; and false memory. All of these concepts are relevant to, and actively considered in, contemporary eyewitness memory research (e.g., Fisher \& Geisleman, 1992 [importance of retrieval cues, including temporal order]; Meissner, Brigham, \& Butz, 2005 [the remember-know distinction]).

In some instances, their descriptions are strikingly similar. For example, in discussing individual differences in memory, Arnold writes:

"Idiosyncracies [sic] are however frequent," says Dr. Ward, "thus we find one person has an exceptional memory for sounds, another for colour, another for forms." The kinds of images ... are as numerous as the different kinds of sensations. ... [A]s visual or auditory images predominate with him, he will have a good memory for sights or sounds. (p. 108)

In a similar vein, Münsterberg says:

[T] here are different types of memory, which ... might be grouped as visual, acoustical and motor types. There are persons who can reproduce a landscape ... while they would be unable to hear internally a melody.... The courts will have to learn, sooner or later, that the individual differences of men can be tested today by the methods of experimental psychology. (pp. 61-63)

\section{Why Has Arnold Been Neglected? (Or, Why Münsterberg?)}

There are a number of possible reasons why Münsterberg has been hailed as the founder of legal psychology and why Arnold's work has been neglected. First, it reflects a natural tendency toward the "great man" approach to history, which singles out select individuals and neglects the larger social, cultural and scientific milieus. This approach inevitably results in an unfair distribution of credit and blame (Thorne \& Henley, 2005). The most visible and outspoken figures tend to garner the lion's share of the credit, and Münsterberg was considerably more visible and outspoken than Arnold and, indeed, than the other pioneers of the field (this exempts figures such as Freud, Binet and James who made occasional references to legal applications of psychology but whose major efforts focused elsewhere). Arnold was not an academician but an obscure civil servant in the furthest reaches of the British Empire. Münsterberg, on the other hand, had a much higher profile during his lifetime. He had a distinguished German academic pedigree (the gold standard in the field at the time) and was a widely known, distinguished professor at Harvard. He was one of the leading psychologists in the U.S. in the early 20th century, on par with figures such as William James and G. Stanley Hall. For example, he served in 1898 as the seventh president of the American Psychological Association (Thorne \& Henley, 2005), and he was a key organizer of the International Congress of Arts and Sciences at the 1904 St. Louis World's Fair, where he ensured that the new science of psychology was well represented (Benjamin, 2004). On the Witness Stand was a best seller published in New York by a leading publisher (Doubleday), whereas Arnold's book was published in Calcutta (by Thacker), which probably affected the availability and distribution of the two works. Thacker published mainly directories that were a combination of almanac and colonial Indian Who's Who, whereas Doubleday was one of, if not the largest English-language publishing house in the early 20th century. ${ }^{2}$ If the publishing industry in the early

2 The information on Thacker comes from http://homepages.rootsweb.com/ poyntz/India/directories.html, and the Doubleday information is from http://www.randomhouse.com/doubleday/history/. The Doubleday website states that after a 1927 merger with George H. Doran Company, it was "the largest publishing concern in the English-speaking world." Interestingly, Frank Nelson Doubleday founded the company in 1897 with magazine publisher Samuel McClure; the fact that Münsterberg had published previously in McClure's likely influenced his choice of publisher for On the Witness Stand. 
20th century was anything like it is in the early 21st century, that undoubtedly would have affected the books' respective marketing and sales prospects.

Münsterberg publicized the nascent field not only by his more scholarly efforts, but also by writing for popular publications and becoming involved in high-profile trials. In addition to McClure's, he wrote occasional pieces for Atlantic Monthly and Mother's Companion. He was involved as a memory expert in several highly publicized trials, such as the 1907 murder-conspiracy trial of "Big Bill" Haywood (Wrightsman, 2001), in which he administered lie-detection tests to assess the truthfulness of a key witness. According to his biographer, Münsterberg was "blessed with an uncanny flair for the sensational" (Hale, 1980, p. 3), and he "became the best-known psychologist in America at a time when the discipline captured the public's fancy" (Hale, p. ix). He was such a vocal mouthpiece for psychology that one observer has characterized him as "a market crier" (Sporer, 2006, p. i).

The second reason for Arnold's comparative neglect is that he was influenced very much by the contemporary zeitgeist in psychology, but he was not an experimental psychologist himself. His work is heavily theoretical, on both the psychological and legal sides. Thus, Arnold's text is more in the philosophical tradition of early psychology, as opposed to Münsterberg's call to arms and to research, an approach sure to resonate more loudly with late 20th and early 21st century researchers. In short, in doing the "new," empirically focused and increasingly applied psychology-which reflected a progressive desire to use science to ameliorate social problems - Münsterberg backed the winning horse.

Third, Arnold did not elicit the virulent sort of response on the part of the legal community that Münsterberg did (Wigmore, 1909), which kept Münsterberg's ideas in the public eye. As noted above, Arnold's tone is relatively tempered and moderate, whereas Münsterberg's tone is more personal and combative. Arnold is critical of legal scholarship, in disputing assumptions made by the law that conflict with psychological evidence; but Münsterberg indicts the entire legal profession, which did not (nor arguably could not) go unanswered. Wigmore's response did not exactly start a dialogue between law and psychology, but it did keep the issues raised by Münsterberg alive; and as the saying goes, there is no such thing as bad publicity.

Fourth, the two authors appear to have had different agendas: Arnold's goal was to lay the philosophical and psychological foundation for addressing fundamental legal questions such as the nature of "intent." Münsterberg's goal was to apply psychology broadly to everyday life, which he sought to do in the legal domain as well as in other areas such as business and industry (Hale, 1980; Wrightsman, 2001).

For these (and perhaps other) reasons, Arnold's work is not cited in early history of psychology texts (e.g., Brett, 1962; Pillsbury, 1929), more recent history of psychology texts or psychology and law texts. ${ }^{3}$ Interestingly, Whipple (1914), the major English- language chronicler of eyewitness research in the early 20th century, does cite Arnold, but he does so dismissively: "[The book] by Arnold, however, can scarcely be said to reflect or embody any of the recent experimental work" (p. x). As we suggest throughout this paper and argue more pointedly in the following section, our field's tendency to ignore Arnold is unfortunate.

\footnotetext{
${ }^{3}$ Brett's third volume of his history of psychology, which was originally published in 1921, roughly contemporaneously with Arnold's work, even covers early law-psychology approaches but makes no mention of Arnold (see Brett, 1962).
} 


\section{What We Can Learn From G. F. Arnold}

As we celebrate the 100th anniversary of the publication of both books, it is worthwhile to consider the extent to which their topics are relevant to the field today. A cursory inspection of the tables of contents of both books shows that we are still pursuing many of the issues Arnold and Münsterberg grappled with, such as suggestibility, insanity, confessions and hypnotism. On the other hand, several other issues that they treat, such as causation and intention (Arnold) and criminal dispositions (Münsterberg), are comparatively ignored by today's psycholegal researchers.

The predominant approach favored by most contemporary psycholegal researchers indeed, by psychological researchers as a whole-is much more akin to Münsterberg's ethos than to Arnold's. The pendulum has shifted, to the point where theory often takes a back seat to application. This tendency is not invariably a bad thing, but experimentation that is fully informed by both legal and psychological theory can greatly enrich both fields (e.g., Wiener, 2007). For example, the influence that psychological research has had thus far in reforming procedures for dealing with eyewitnesses has occurred largely because of the research's solid grounding in psychological theory (e.g., Lane \& Meissner, 2008; Lindsay, Ross, Read, \& Toglia, 2007; Toglia, Read, Ross, \& Lindsay, 2007; Wells, Memon, \& Penrod, 2006). An overemphasis on application or theory, to the exclusion of the other, does not serve the field well for a number of reasons, not least because in assessing the value of scientific research, courts and policy-makers generally require both verisimilitude in experimental methods and scientific rigor (see e.g., papers in this issue by Clark, 2008; Deffenbacher, 2008; Malpass et al., 2008; Turtle, Read, Lindsay, \& Brimacombe, 2008). To some extent, Arnold's and Münsterberg's works are exemplars of the "basic" and "applied" extremes, respectively, and considering them jointly can provide useful guidance to future eyewitness researchers.

Moreover, any field can benefit, in taking stock of where it is currently, from a consideration of where it has been and a reexamination of its founding principles (Kuhn, 1970). In that sense, we can learn a great deal from the themes raised in Münsterberg's and Arnold's texts. A close examination of these texts allows us to look back from our present vantage point and attempt to answer some critical questions. It is beyond the scope of the present paper to provide thorough answers to these questions, but we do offer thumbnail responses, along with suggestions for further reading. First, how far have we come as a field? In our estimation, the answer is "Quite far, but not nearly far enough." In particular, the healthy debate over methodological issues and the adequacy of research findings shows that there is much work still to be done (e.g., Malpass et al., 2008; Memon, Mastroberardino, \& Fraser, 2008; Penrod \& Bornstein, 2006; Turtle et al., 2008). Second, do we have answers to any of the questions that Arnold and Münsterberg raised? Yes. Several papers in the present issue illustrate nicely that there is an established scientific basis for drawing conclusions on a number of topics, such as the confidence-accuracy relation (Brewer \& Weber, 2008; Deffenbacher, 2008), decision latency (Brewer \& Weber, 2008), stress (Deffenbacher, 2008; Memon et al., 2008), the retention interval (Deffenbacher, 2008), and lineup composition and instructions (Clark, 2008). This is not to suggest that the book is necessarily "closed" on these topics; research areas continually evolve as new questions arise, new methods are developed, and so forth (Malpass et al., 2008). Third, what topics have we (perhaps unrightly) ignored? Precisely because system needs and research paradigms change over time, this question is harder (and perhaps impossible) to answer. Often we are unaware of having ignored an important topic until the need arises. Merely 
asking the question, as well as others raised by taking a historical perspective/retrospective, will enable contemporary psycholegal researchers to continue making valuable contributions to policy debates surrounding eyewitness memory and other issues at the intersection of psychology and law.

\section{Acknowledgments}

We thank the organizers and audience members where this work was previously presented for several helpful suggestions, Chris Meissner and Sean Lane for useful comments on an earlier draft of this paper, and Ani Aharonian for technical assistance.

\section{References}

Arnold, G. F. (1897). Monograph on cotton fabrics and the cotton industry in Burma. Rangoon: Supdt., Govt. Printing.

Arnold, G. F. (1906). Psychology applied to legal evidence and other constructions of law. Calcutta: Thacker, Spink \& Co.

Bartol, C. R., \& Bartol, A. M. (2004). Introduction to forensic psychology. Thousand Oaks, CA: Sage.

Benjamin, L. T. (1997). The origin of psychological species: History of the beginnings of American Psychological Association divisions. American Psychologist, 52, 725-732.

Benjamin, L. T. (2000). Hugo Münsterberg: Portrait of an applied psychologist. In G. A. Kimble, \& M. Wertheimer (Eds). Portraits of pioneers in psychology (Vol. 4, pp. 113-129). Mahwah, NJ: Erlbaum.

Benjamin, L. T. (2004). Meet me at the fair: A centennial retrospective of psychology at the 1904 St. Louis World's Fair. APS Observer, 17, 9-12.

Benjamin, L. T. (2006). Hugo Münsterberg's attack on the application of scientific psychology. Journal of Applied Psychology, 91, 414-425.

Best, W. M. (1849). A treatise on the principles of evidence and practice as to proofs in courts of common law. London: S. Sweet.

Binet, A. (1900). La suggestibilité. Paris: Schleicher Frères.

Brett, G. S. (1962). Brett's history of psychology (ed. and abridged by R. S. Peters). London: Allen \& Unwin.

Brewer, N., \& Weber, N. (2008). Eyewitness confidence and latency: Indices of memory processes not just markers of accuracy. Applied Cognitive Psychology, 22, 827-840.

Clark, S. E. (2008). The importance (necessity) of computational modelling for eyewitness identification research. Applied Cognitive Psychology, 22, 803-813.

Costanzo, M. (2004). Psychology applied to law. Belmont, CA: Thomson/Wadsworth.

Deffenbacher, K. A. (2008). Estimating the impact of estimator variables on eyewitness identification: A fruitful marriage of practical problem solving and psychological theorizing. Applied Cognitive Psychology, 22, 815-826.

Doyle, J. M. (2005). True witness: Cops, courts, science, and the battle against misidentification. New York: Palgrave Macmillan.

Fisher, R. P., \& Geisleman, R. E. (1992). Memory-enhancing techniques for investigative interviewing: The cognitive interview. Springfield, IL: Charles C. Thomas.

Greene, E., Heilbrun, K., Fortune, W. H., \& Nietzel, M. T. (2006). Wrightsman's psychology and the legal system (6th ed.). Belmont, CA: Wadsworth/Thomson.

Gross, H. (1897/1905). Kriminalpsychologie. Graz: Teuschner \& Lubensky.

Hale, M. (1980). Human science and social order: Hugo Münsterberg and the origins of applied psychology. Philadelphia: Temple University Press. 
Kuhn, T. (1970). The structure of scientific revolutions. Chicago: University of Chicago Press.

Lane, S. M., \& Meissner, C. A. (2008). A "middle road" approach to bridging the basic-applied divide in eyewitness identification research. Applied Cognitive Psychology, 22, 779-787. doi

Lindsay, R. C. L., Ross, D. F., Read, J. D., \& Toglia, M. P. (2007). Handbook of eyewitness psychology Memory for events (Vol. 1). Mahwah, NJ: Erlbaum.

Lombroso, C. (1876). L'Uomo delinquente. Milan: Hoepli.

Malpass, R. S., Tredoux, C. G., Compo, N. S., McQuiston-Surrett, D., MacLin, O. H., Zimmerman, L. A., et al. (2008). Study space analysis for policy development. Applied Cognitive Psychology, 22, 789-801.

Meissner, C. A., Brigham, J. C., \& Butz, D. A. (2005). Memory for own- and other-race faces: A dualprocess approach. Applied Cognitive Psychology, 19, 545-567.

Memon, A., Mastroberardino, S., \& Fraser, J. (2008). Münsterberg's legacy: What does eyewitness research tell us about the reliability of eyewitness testimony? Applied Cognitive Psychology, 22, 841-851.

Münsterberg, H. (1908). On the witness stand. New York: Clark, Boardman.

Penrod, S., \& Bornstein, B. H. (2007). Generalizing eyewitness reliability research. In R. C. L. Lindsay, D. F. Ross, J. D. Read, \& M. P. Toglia (Eds.), The handbook of eyewitness psychology (Vol. 2): Memory for people (pp. 529-556). Mahwah, NJ: Erlbaum.

Pillsbury, W. B. (1929). The history of psychology. London: George Allen and Unwin, Ltd.

Spillmann, J., \& Spillmann, L. (1993). The rise and fall of Hugo Münsterberg. Journal of the History of the Behavioral Sciences, 29, 322-338.

Sporer, S. L. (1992). A brief history of the psychology of testimony. Current Psychology, 2, 323-339.

Sporer, S. L. (2006). Editorial: The science of eyewitness testimony has come of age. Psychological Science in the Public Interest, 7 , i-ii.

Sporer, S. L. (2008). Lessons from the origins of eyewitness testimony research in Europe. Applied Cognitive Psychology, 22, 737-757.

Stephen, J. F. (1883). History of the criminal law of England. London: Macmillan \& Co.

Stern, W. (1907-1908). Literatur zur Psychologie der Aussage. Zeitschrift für Angewandte Psychologie, 1, 429-450.

Thorne, B. M., \& Henley, T. B. (2005). Connections in the history and systems of psychology (3rd ed.). Boston: Houghton Mifflin Co.

Toglia, M. P., Read, J. D., Ross, D. F., \& Lindsay, R. C. L. (2007). Handbook of eyewitness psychology Memory for events (Vol. 1). Mahwah, NJ: Erlbaum.

Turtle, J., Read, J. D., Lindsay, D. S., \& Brimacombe, C. A. E. (2008). Toward a more informative psychological science of eyewitness evidence. Applied Cognitive Psychology, 22, 769-778. doi

Wells, G. L., Memon, A., \& Penrod, S. D. (2006). Eyewitness evidence: Improving its probative value. Psychological Science in the Public Interest, 7, 45-75.

Whipple, G. M. (1909). The observer as reporter: A survey of the psychology of testimony. Psychological Bulletin, 6, 153-170.

Whipple, G. M. (1910). Recent literature on the psychology of testimony. Psychological Bulletin, 7, 365-368.

Whipple, G. M. (1911). The psychology of testimony. Psychological Bulletin, 8, 307-309.

Whipple, G. M. (1912). Psychology of testimony and report. Psychological Bulletin, 9, 264-269.

Whipple, G. M. (1913). Psychology of testimony and report. Psychological Bulletin, 10, 264-268.

Whipple, G. M. (1914). Psychology of testimony and report. Psychological Bulletin, 11, 245-250.

Wiener, R. L. (2007). Law and everyday decision making: Rational, descriptive, and normative models. In R. L. Wiener, B. H. Bornstein, R. Schopp, \& S. L. Willborn (Eds.), Social consciousness in legal decision making: Psychological perspectives (pp. 3-32). New York: Springer.

Wigmore, J. H. (1909). Professor Muensterberg and the psychology of testimony. Illinois Law Review, 3, 399-445.

Wrightsman, L. S. (2001). Forensic psychology. Belmont, CA: Wadsworth/Thomson. 